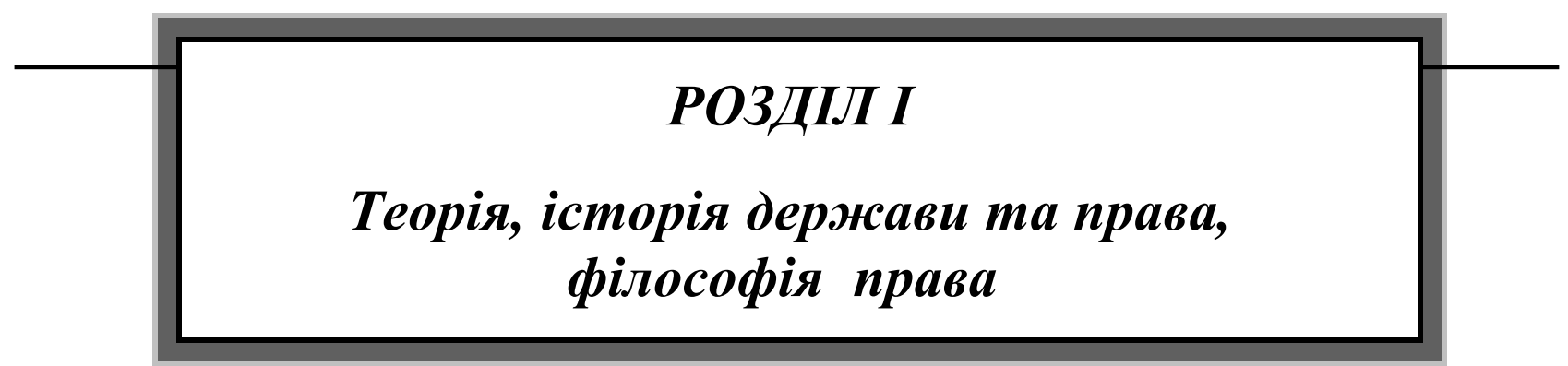

УДУ 343(477)(091)"1529"

DOI https://doi.org/10.32782/2409-4544/2019-2/1

М. Яциишин

\title{
Нововведення в загальних положеннях кримінального права та майнових покараннях за Першим Литовським Статутом 1529 p.
}

Розглянуто норми регулювання кримінального права, принципи здійснення судочинства, викладені в Першому Литовському Статуті 1529 р. Ця пам'ятка права базувалася на положеннях Руської Правди, нормах звичаєвого права і ряді норм польського і німецького судебників. Норми кримінального права в Литовському Статуті 1529 р. були поміщені в дванадцятий і тринадцятий розділи. Однак по кримінально-правові норми також містилися i в інших розділах Статуту. Розглянуто нововведення в загальних положеннях кримінального права, які дозволяють зробити висновок про те, що норми Литовського Статуту 1529 р. увібрали в себе гуманістичні ідеї рівності всіх перед законом, однак на практиці реалізація цих норм залишилася не здійсненою. В частині регулювання майнових покарань нововведенням стала головщина, однак i це покарання застосовувалося лише як додаткове. Перший Статут Великого Князівства Литовського у своїх нормах був значним прогресом у процесі систематизації та кодифікації середньовічного кримінального права не лише на теренах України, але і всієї Свропи. При розробці Статуту були вперше вирішені такі складні теоретичні і практичні питання, як поділ норм права по галузях, розміщення їх в певній системі. Хоча в Статуті 1529 р. і передбачалося збереження привілеїв і пільг у галузі кримінального права для панівних верств населення, проте його норми проголошували загальний правопорядок, що, безумовно, було значним кроком для розвитку тогочасного права. Законодавець у Литовському Статуті 1529 р. передбачив нові для кримінального права принципи і продовжив розвивати попередні, зокрема, на законодавчому рівні була проголошена рівність всіх вільних людей перед законом, притягнення до відповідальності тільки в судовому порядку та індивідуалізація покарання. головщина.

Ключові слова: Литовський Статут 1529 р., кримінальне право, майнові покарання,

Постановка наукової проблеми та їі значення. Литовський статут 1529 р. був фактично першим кодифікованим збірником положень та законів, що діяли на землях Речі Посполитої. Прогресивність даного продукту законотворення полягала в застосуванні систематизації законів в єдиному документі, що фактично являвся кодексом, в котрому поєднувалися існуючі на той час галузі права. Згідно з припущенням Н. А. Максименка, Старий Литовський статут ввібрав в собі основні правові норми попереднього законодавства, юрисдикція котрого поширювалася на всі Руські та Литовські землі.

Мета статті. В поданій публікації пропонуємо проаналізувати норми кримінального права, вміщені до Статуту 1529 р., оскільки даний правовий аспект частково лишився поза увагою досліджень науковців.

Виклад основного матеріалу й обгрунтування отриманих результатів дослідження. Литовський статут (1529р.) по завершенню детального обговорення був прийнятий сеймом у м. Вільнюсі 29 вересня 1529 року. Означений нормативний документ було розподілено на 13 розділів та 264 статті або артикули.

(C) Яичишин М., 2019 
Норми державного права, основоположні засади інших галузей права знайшли своє відображення у перших трьох розділах. Відносини у сфері сімейного та спадкового права були регламентовані нормами п'ятого розділу. У шостому розділі врегульовувались правовідносини у сфері кримінального права, у восьмому - земельного права, у дев'ятому - лісового та мисливського.

Цивільно-правові відносини регулювались положеннями одинадцятого розділу Литовських Статутів (1529р.), а кримінально-процесуальні були регламентовані нормами дванадцятого та тринадцятого розділу означеного правового акту [8, с. 22].

У вказаному нормативному документі отримали юридичне закріплення основи суспільного та державного устрою, правове положення всіх соціальних груп населення, порядок освіти, склад та повноваження деяких органів державного управління та суду [5, с. 47].

Розглядаючи положення Литовського Статуту (1529р.), Т. І. Ісманицька вказує, що його унікальність полягає у тому, що кодифікаторам внаслідок значної теоретичної роботи вдалося створити таку систему права, яка була однаково прийнята в усіх кінцях величезної різноманітної держави. Вказаний нормативний документ органічно поєднав деякі положення Руської Правди, норми звичаєвого (українського, білоруського, литовського) права, ряд пунктів 3 польського та німецького судебників, зокрема, Саксонського Зерцала. Останній значною мірою вплинув на формування правових систем Центральної Свропи [2, с. 98].

Проведені на даний час дослідження відносно норм кримінального права проводилися лише 3 огляду на вузьку спеціалізацію норм Литовського статуту. Відзначимо, що нормам кримінального права в означеному нами правовому акті відведено дванадцятий та тринадцятий розділи і загалом присвячено сорок чотири артикули. Однак певні аспекти кримінального права зустрічаються і в інших розділах.

Особливої уваги в процесі аналізу даного правового джерела заслуговують норми регулювання кримінального права, оскільки даний правовий аспект лишився поза увагою досліджень.

Перший Статут Великого Князівства Литовського у своїх нормах мав значний прогрес в процесі систематизації та кодифікації середньовічного кримінального права не лише на теренах України, але і всієї Європи. При розробці Статуту були вперше вирішені такі складні теоретичні і практичні питання, як поділ норм права по галузях, розміщення їх в певній системі.

Хоча в Статуті 1529 року і передбачалося збереження привілеїв і пільг в галузі кримінального права для панівних верств населення, проте його норми проголошували загальний правопорядок, що, безумовно, було значним кроком для розвитку тогочасного права. Так, в статті сьомій розділу першого проголошувався принцип відповідальності тільки за свою провину, принцип призначення покарання тільки особам, вина яких встановлена в судовому порядку. Подібні прогресивні принципи містяться і в нормах наступних артикулів. Це означає, що вони стали базовими принципами кримінального права XVI ст. [3, с. 58]. Статут 1529 року став основою для подальшого розвитку законодавства і подальшої розробки Литовських Статутів.

Законодавець у Статуті 1529 р. вмістив нові для кримінального права принципи і продовжив розвивати попередні, зокрема, на законодавчому рівні була проголошена рівність всіх вільних людей перед законом, притягнення до відповідальності тільки в судовому порядку та індивідуалізація покарання [2, с. 4].

Статут 1529 року містив ряд прогресивних норм, у яких знайшли своє відображення ідеї гуманізму. Так, у статті 7 розділу I проголошувалось, що ніхто не повинен нести покарання за чужу провину, а кримінальні покарання слід виносити тільки тим особам, винність яких встановлено судом. У статті 27 розділу VII встановлювались терміни давності кримінального переслідування: за найбільш тяжкі злочини - 10 років; за менш тяжкі злочини - 3 роки [4, с. 48]. У статті 7 розділу VII була проведена спроба обмежити джерела кріпацтва («холопства»). Вільна людина за скоєння злочину не повинна була потрапити у довічне закріпачення.

У Першому Литовському Статуті були також передбачені окремі принципи здійснення судочинства. Так, наприклад, проголошувалось правило, за котрим суб'єкти права та учасники судових процесів більше не мали поділу за майновим статусом і повинні бути судимі тільки за положеннями, викладеними у Статуті. Перший Статут передбачав принцип гласності здійснення судочинства, формальної рівності сторін у процесі, право обвинуваченого на захист за участю адвоката.

Однак, на противагу зазначеним прогресивним нормам також гарантувалось право збереження привілегій та пільг знаті. На практиці це призводило до цілковитого нехтування правами переважної більшості населення та концентрації всієї повноти прав у руках заможних верств [8, c. 49]. Фактично за ними закріплювалась необмежена та постійна влада над селянами. Залежне 
становище останніх було відображено у нормі про фактично повну безправність селянина та прирівняння його до власності магната чи шляхтича без збереження за ним особистих прав. Так, зокрема за вбивство селянина, винний повинен був заплатити лише «головщину» (певну суму грошей) його власнику, яка повинна була покрити збитки, завдані пану [5, с.116]. Проте, навіть формальне проголошення рівності прав населення незалежно від майнового та соціального статусу у зазначений період вже було прогресивним та демонструвало високий розвиток правової думки.

Положення Першого Статуту також передбачали можливість залучення до судового процесу адвоката. Ним міг бути тільки шляхтич, уродженець Великого князівства Литовського, який мав нерухоме майно (тобто був «осілим») та мав дозвіл суду на заняття адвокатською практикою, а також характеризувався пристойною поведінкою. Обов'язковою умовою для заняття адвокатською діяльністю було знання не лише загальних законів, котрі діяли у державі, але й знання місцевого права. Окрім участі адвоката, для захисту прав сторони дозволялось процесуальне правонаступництво, тобто передача прав та обов'язків від однієї особи до іншої [6, с. 51].

Статут 1529 року встановлював та регламентував судово-процесуальне право. Суд був основним органом охорони правопорядку. Його діяльність була направлена на обмеження свавілля окремих підданих та підвищення авторитету права. Суд у той час знаходився у центрі суспільного життя шляхти [7, с. 49].

Вся судова система Великого князівства Литовського за Статутом 1529 року будувалась за родовим принципом з урахуванням соціального стану. Найвищим судом у державі був великокняжий суд. До його складу входили великий князь з панами-радниками. В певних випадках верховний суд чинили самі пани-радники, за дорученням Великого князя Литовського. До юрисдикції великокняжого суду входили справи феодалів і дуже рідко справи простолюдинів. Судові функції на місцях виконували посадові особи місцевого управління, а саме, воєводи, старости, державці.

Перелічені категорії державослужбовців здійснювали судочинство самостійно або ж могли делегувати функції своїм намісникам, призначеним з кола місцевої шляхти. Такі суди розглядали судові питання стосовно шляхти, адже суд над залежними особами здійснювався панами. Окремі справи відносно простих людей розглядались копними судами. Міщани судились у війтівсько-копних судах $[8$, с. 50$]$.

Статутом 1529 р. передбачалася чітка та структурована система покарань. Як зазначає Г. Демченко, за Першим Литовським Статутом покарання представляло здебільшого засіб компенсації шкоди, завданої потерпілому. Лише в певних випадках воно було спрямоване як вплив на волю та світогляд злочинця, а мета залякування практично не переслідувалася [1, с. 172].

У зв'язку з цим, основною формою стали саме майнові покарання, які були першочергово спрямовані на компенсацію збитків завданих потерпілому, також враховувалась потреба компенсації для громадськості у вигляді спеціалізованих штрафів на користь влади.

Враховуючи особливе значення майнових покарань за Статутом 1529 р., варто звернути увагу на головщину, адже саме це майнове покарання законодавець вважав найважчим. За твердженням проф. В. Кульчицького, головщина - це грошовий штраф «за голову убитого», тобто відшкодування злочину, котрий посягає на життя особи за допомогою виплати коштів. Однак головщина розглядається законодавцем лише як додатковий вид покарання, котрий застосовується одночасно 3 прийняттям інших мір і спрямований на часткову компенсацію втрати родичам потерпілого.

За Статутом 1529 р. головщина призначалася додатково до покарання навязкою. За наступними редакціями головщина призначалася разом зі смертною карою. Статут 1529 року в плані матеріальних відшкодувань та покарання знаходився на стадії раннього становлення і закріплення лише найбільш важливих, на думку законодавця, положень. Норми головщини були прописані лише в чотирьох артикулах одинадцятого розділу. Однак, незважаючи на доволі малий об'єм, вони все ж дають можливість визначити найбільш характерні риси головщини як виду кримінального покарання.

Відзначимо, що для злочинця головщина була покаранням, для потерпілого відшкодуванням за завдану шкоду [1,63]. Головщина мала на меті відшкодування матеріальних втрат, завданих внаслідок смерті особи [1, с. 63]. На відміну від більш пізніх редакцій Литовського Статуту, перша законодавча збірка визначала досить вузьке коло злочинів, за вчинення яких карали головщиною. Зокрема, це вбивство людини путньої (арт. 1 розд. 11), вбивство бортника (арт. 1 розд. 11), вбивство ремісника (арт. 2 розд. 11), вбивство тивуна, пристава і ключника при виконанні ними обов'язків (арт. 3 розд. 11), вбивство тяглового селянина (арт. 4 розд. 11), вбивство невільного парубка (арт. 4 розд. 11) і вбивство невільної жінки (арт. 4 розд. 11).

Розмір головщини залежав не тільки від важкості злочину, а й від соціального статусу вбитого $[1,63]$. Так, наприклад, за вбивство «людини путньої» передбачалося покарання у розмірі 12 
коп грошей (арт. 1 розд. 11), за вбивство тяглого селянина - 10 коп грошей, а за вбивство «невільного парубка» - 5 коп грошей.

Впливав на розмір головщини і соціальний стан вбитого. Особливо показовими в цьому плані були артикули третій та четвертий розділу одинадцятого, які передбачали за вбивство челядника 5 коп грошей (арт. 4 розд. 11), а за вбивство челядника, виконуючого обов'язки тивуна або пристава 10 коп грошей. Підвищувався рівень головщини і за вбивство ремісників, «навіть, якщо хто-небудь 3 цих ремісників тяглий або невільний» (арт. 2 розд. 11), причому відразу 310 і 5 коп грошей відповідно до 12 рублів Литовських.

Висновки. Отож, підсумовуючи матеріал, викладений у поданій статті, можна зробити наступні висновки:

Перший Литовський Статут 1529 р. базувався на положеннях Руської Правди, нормах звичаєвого права та ряду пунктів 3 польського та німецького судебників.

Норми кримінального права в Статуті 1529 р. були вміщені до дванадцятого та тринадцятого розділів. Однак, щодо кримінального права певні норми також містилися і в інших розділах.

Розглянуті нами питання щодо нововведень загальних положень кримінального права дозволяють підсумувати, що норми Старого Литовського статуту ввібрали в себе певні гуманістичні ідеї рівності всіх перед законом, однак на практиці реалізація поданих норм лишилася нереалізованою.

Щодо майнових покарань нововведенням стала головщина, однак і це покарання застосовувалося лише як додаткове.

\section{Джерела та література}

1. Демченко Г. Наказаніе по Литовському Статуту въ его трехъ редакціях (1529, 1566 и 1588 гг.) / Г. Демченко. - Кіевъ: Типографія Императорскаго Университета св. Владиміра, 1894. - 276 с.

2. Захарченко П. Історія держави і права України / П. Захарченко. - Київ: Атіка, 2005. - 368 с.

3. Кульчицький В., Тищик Б. Історія держави і права України / В. Кульчицький, Б. Тищик. - Львів: ЛНУ, 2000. -402 с.

4. Майкут X. Литовські статути та їх застосування в Україні / X. Майкут // Науковий вісник Львівського державного університету внутрішніх справ. -2008. - № 2. - С. 34-42.

5. Первый или Старый Литовский Статут // Временник Общества истории и древностей Российских. - 1854. - Кн. 18. - С. 1-106.

6. Терлюк I. Історія українського права від найдавніших часів до XVIII століття / I. Терлюк. - Львів: Львівський інститут внутрішніх справ при НАВС України, 2003. - 156 с.

7. Кузнецов И. Н., Шелкопляс В. А. История государства и права Беларуси: пособие для студентов ВУЗ / И. Н. Кузнецов, В. А. Шелкопляс. - Минск: Дикта, 2004. - 272 с.

8. Довнар Т. И., Шелкопляс В. А. Уголовное право феодальной Беларуси (XV-XVI вв.): учебное пособие / Т. И. Довнар, В. А. Шелкопляс. - Минск: Изд-во Акад. МВД Респ. Беларусь, 1995. - 96 с.

Яцишин М. Нововведения в общих положениях уголовного права и имущественных наказаниях в Первом Литовском Уставе 1529 г. Рассмотрены нормы регулирования уголовного права, принципы осуществления судопроизводства, изложенные в Литовском Уставе 1529 г. Первый Литовский Устав 1529 г. базировался на положениях Русской Правды, нормах обычного права и ряде норм польского и немецкого судебников. Нормы уголовного права в Литовском Уставе 1529 г были помещены в двенадцатый и тринадцатый разделы. Однако по уголовно-правовые нормы также содержались и в других разделах Устава. Рассмотрены нововведения в общих положениях уголовного права, которые позволяют сделать вывод о том, что нормы Литовского Устава 1529 г. впитали в себя определенные гуманистические идеи равенства всех перед законом, однако на практике реализация представленных норм осталась нереализованной. В части регулирования имущественным наказаний нововведением стала головщина, однако и это наказание применялось лишь как дополнительное. Первый Статут Великого Княжества Литовского в своем содержании был значительным прогрессом в процессе систематизации и кодификации средневекового уголовного права не только в Украине, но и во всей Европе. При разработке Устава были впервые решены такие сложные теоретические и практические вопросы, как разделение норм права по отраслям, размещение их в определенной системе. Хотя в Уставе 1529 и предполагалось сохранение привилегий и льгот в области уголовного права для господствующих слоев населения, однако его нормы провозглашали общий правопорядок, что, безусловно, было значительным шагом для 
развития тогдашнего права. Законодатель в Литовском Уставе 1529 г. предусмотрел новые для уголовного права принципы и продолжил развивать предыдущие, в частности, на законодательном уровне было провозглашено равенство всех свободных людей перед законом, привлечение к ответственности только в судебном порядке и индивидуализация наказания.

Ключевые слова: Литовский Устав 1529 г., уголовное право, имущественные наказания, головщина.

Yatsyshyn M. Innovations in the General Provisions of Criminal Law and Property Penalties under the First Lithuanian Statute of 1529. The article considers the rules of criminal law and the principles of the administration of justice, set out in the Lithuanian Statute of 1529. The first Lithuanian of 1529 was based on the provisions of Rus'ka Pravda, the norms of Common law, and a number of articles from the Polish and German Codes of law. The provisions of criminal law were lodged in chapters twelve and thirteen of the Statute of 1529, however other Statute chapters also contained certain norms of the criminal law. The study of the issues regarding the innovations in the general provisions of the criminal law allows to conclude that the norms of the Old Lithuanian Statute have incorporated the humanistic ideas of equality before the law, but in practice, the implementation of these norms remained unrealized. With regard to the property punishments, the study has revealed an innovative form of punishment - holovshchyna (in Rus'ka Pravda a fine for the «head of the killed» paid to the family or his relatives). However, it was applied only as an additional or supplementary one. The first Statute of the Grand Duchy of Lithuania in its norms had significant progress in the process of systematization and codification of medieval criminal law not only in Ukraine but in Europe too. During the development of the Statute, such complex theoretical and practical issues as the division of legal norms by branches and their placement in a certain system were resolved for the first time. Although the Statute of 1529 provided for the saving of privileges in the field of criminal law for the ruling classes, but its norms proclaimed the general rule of law, which, of course, was a significant step for the development of law at that time. The legislator in the Statute of 1529 contained new principles for criminal law and continued to develop the previous ones, such as the equality of all free people according the law, which was proclaimed at the legislative level, prosecution only in the court and individualization of punishment.

Key words: Lithuanian Statute of 1529, criminal law, property penalties, holovshchyna.

УДК : 342.7 (093)

DOI https://doi.org/10.32782/2409-4544/2019-2/2

С. Булавіна

\section{Генеза гарантій прав та свобод людини й громадянина в Україні: історико-правове дослідження}

У статті досліджено історико-правову думку про гарантії прав і свобод людини та громадянина. Досліджено становлення та розвиток ідеї гарантій прав і свобод людини та громадянина в України. У вітчизняній скарбниці історико-правових досліджень проблематики прав і свобод людини та їх гарантій гідне місце займає спадщина Павла Русина (1450-1517рр.). Цікавими та прогресивними ідеями, які сприяють закріпленню прав і свобод людини, насичена творчість типового представника українського гуманістичного руху першої половини XVIст. - філософа, історика та політолога Станіслава Оріховського-Роксолана (1513-1566 рр.). Одним з перших серед вітчизняних мислителів Інокентій Гізель (1600-1683 рр.) поставив природне право як критерій людської поведінки вище від закону Божого, доповнюючи критерій добра і зла розумом, який, пізнавши закони природи, керує вчинками людини відповідно до цих законів. Встановлено, що на державу та ії органи Конституція і закони України покладають обов'язки по забезпеченню прав і свобод людини та громадянина. Так, у ст. 3 Конституції України визначено головний зміст та спрямованість діяльності держави - права і свободи людини та їх гарантії. Історико-правові ідеї, висунуті видатними вченими, стали витоками і основою всіх суспільно-правових відносин, закріплення обов'язку держави захищати права і свободи людини, створили необхідні передумови для формування в суспільстві вимог гарантованості прав і свобод та поступового їх доповнення новими принципами та інститутами

(C) Булавіна С., 2019 